\title{
UPAYA PENGUATAN BADAN PENELITIAN DAN PENGEMBANGAN KOTA SAMARINDA PASCA PENERAPAN PERATURAN PEMERINTAH NOMOR 38 TAHUN 2017 TENTANG INOVASI DAERAH
}

\author{
THE EFFORT OF STRENGTHENING RESEARCH AND \\ DEVELOPMENT AGENCY IN SAMARINDA MUNICIPALITY AFTER \\ THE IMPLEMENTATION OF GOVERNMENT REGULATION NO.38 \\ OF 2017 CONCERNING REGIONAL INNOVATION
}

\author{
Tri Wahyuni dan Tri Noor Aziza \\ PKP2A III Lembaga Administrasi Negara \\ Jl.H.M. Ardan (Ringroad III) Samarinda \\ Email: triw728@gmail.com dan iza.aziza@gmail.com \\ Naskah diterima : 19Desember 2017, Direvisi : 24 Januari 2018, \\ Disetujui : 30Januari 2018
}

\begin{abstract}
Innovation can create better bureaucracy. Article 386 paragraph 1 Law Number 23 Year 2014 concerning Local Government states that in order to improve local government performance, the local governments can create innovations. The successful innovation in Samarinda Municipality in 2016 isa great capital to continue the innovations'success stories in the municipality. Following the issuance of Government Regulation Number 38 Year 2017 concerning Regional Innovation, it is explicitly mentioned that regional innovation is coordinated by the heads of Research and Development ( $R \& D)$ Agency. Applying qualitative approach throughliterature study, this reasearch examines the role of the agency in performing its tasks based on the government regulation. This study aims to contribute ideasabout any possible effort that can be done by $R \& D$ Agencyin Samarinda Municipality in carrying out its function as mentioned in Government Regulation Number 38 Year 2017 concerning Regional Innovation. Result of the research indicates that the agency must strengthen itself as organization in charge of regional innovation by providing criteria for regional innovation, becoming Independent Team Coordinator for local innovation innitiatives derived from local government leader, local parliament member, civil servant, and local government apparatus. The Agency must have ability to think and work fast. The agency must also improve its human resources, both in quantity and quality aspects. Finally, the agency must obtain additional budget to support its coordinating job to improve the Regional Innovation System (SIDa).
\end{abstract}

Keywords: organization strengthening, research and development Agency, innovation. 


\begin{abstract}
Abstrak
Inovasi dapat menciptakan birokrasi yang lebih baik. Pasal 386 ayat (1) UU No. 23 Tahun 2014 tentang pemerintahan daerah menyebutkan bahwa dalam rangka peningkatan kinerja penyelenggaraan pemerintahan daerah, pemerintah daerah dapat melakukan inovasi. Kesuksesan inovasi Kota Samarinda di tahun 2016 merupakan modal besar untuk melanjutkan kisah sukses selanjutnya tentang inovasi di lingkungan Pemerintah Kota Samarinda. Setelah terbitnya No. 38 Tahun 2017 tentang Inovasi daerah, secara eksplisit disebutkan bahwa inovasi daerah dikoordinasikan oleh Kepala Perangkat Daerah yang membidangi penelitian dan pengembangan.Jika peran Badan Penelitian dan Pengembangan Kota Samarinda yang begitu besar sebagai leading sector tidak segera merespon tugas dan fungsinya melalui upaya pemetan terhadap segala peluang dan hambatan, maka dikhawatirkan akan dapat menghambat keseluruhan proses inovasi di Pemerintah Kota Samarinda. Dengan menggunakan pendekatan kualitatif melalui studi pustaka terhadap peraturan. Penelitian ini bertujuan untuk memberikan kontribusi pemikiran tentang berbagai langkah konkrit yang dapat dilakukan Badan Penelitian dan PengembanganKota Samarinda dalam menjalankan fungsi inovasi sebagaimana yang tersebut di dalam PP. No. 38 tahun 2017 tentang Inovasi Daerah.Dari hasil analisa penelitian, yang harus dilakukan oleh Balitbangda untuk melakukan upaya penguatan terhadap organisasinya berdasarkan PP No. 38 tahun 2017 antara lain: memberi input terhadap kriteria inovasi daerah, menjadi Koordinator Tim Independen atas inisiatif Inovasi daerah yang berasal dari Kepala Daerah, anggota DPRD, Aparatur Sipil Negara, dan Perangkat Daerah. Balitbangda harus memiliki kemampuan untuk berpikir dan bekerja cepat. karena waktu untuk evalusi terhadap inisiatif inovasi paling lama 10 (sepuluh) hari kerja.Balitbangda Kota samarinda juga harus melakukan pembenahan SDM, baik dari segi kuantitas maupun kualitasnya. Berkaitan dengan anggaran, Balitbangda harus mendapatkan tambahan alokasi anggaran yang representatif untuk menunjang pelaksanaan fungsi - fungsi koordinasi inovasinya serta upaya untuk mewujudkan penguatan Sistem Inovasi daerah (SIDa).
\end{abstract}

Kata Kunci :Penguatan Organisasi, Inovasi, Penelitian dan Pengembangan

\title{
A. PENDAHULUAN
}

Pergeseran paradigma merupakan suatu kepastian dalam kehidupan masyarakat dunia yang sudah masuk ke dalam era globalisasi. Dalam paradigma lama, menjadi bagian bangsa yang kaya akan sumber daya alamnya, tentu akan membawa kesejahteraan. Kini, paradigma tersebut telah bergeser, fakta telah menunjukkan bahwa, negara minim sumber daya alam pun bisa menjelma menjadi negara besar dari segi perekonomian, teknologi, dan kesejahteraannya. Bank Dunia dalam laporan terbarunya terkait kemudahan berbisnis (Ease of Doing Business/EODB) 2018, menempatkan New Zeland pada peringkat pertama kemudahan berbisnis dengan skor 86,55 dan Singapura di peringkat kedua dengan skor 84.57. Sedangkan Indonesia menduduki posisi ke 72, naik 19 peringkat dibandingkan tahun 2017 di posisi 91. Kendati demikian, peringkat Indonesia masih tertinggal dibandingkan negara-negara tetangga, seperti Malaysia di peringkat ke-24 dengan skor 78,43, Thailand di peringkat ke-26 dengan skor 77,44, dan Vietman di peringkat ke-68 dengan skor 67,93. Karena itu Presiden Joko Widodo menargetkan Indonesia dapat masuk dalam peringkat 40 besar pada 2019 mendatang (CNN Indonesia, 2017). Guna mendukung kebijakan presiden 
tersebut, semua sumber daya harus bergerak untuk menunjang perubahan yang diinginkan, termasuk birokrasi. Birokrasi dituntut untuk merubah sistem kerja menjadi lebih mudah, lebih cepat, dan lebih ringkas prosedurnyayang diwujudkan dengan perubahan bernama inovasi.

Inovasi diyakini dapat mengantarkan kondisi birokrasi menjadi lebih baik, dalam Pasal 386 ayat (1) UU No. 23 Tahun 2014 tentang Pemerintahan Daerah menyebutkan bahwa dalam rangka peningkatan kinerja penyelenggaraan pemerintahan daerah, pemerintah daerah dapat melakukan inovasi. Ayat (2) menyebutkannya bahwa yang dimaksud dengan inovasi adalah semua bentuk pembaharuan dalam penyelenggaraan Pemerintahan Daerah. Sementara bagaimana sebuah inovasi dirumuskan, dapat dilihat pada prinsip inovasi sebagaimana tersebut di dalam Pasal 387. Menteri Dalam Negeri, Tjahjo Kumolo, menyebutkan bahwa inovasi yang dilakukan oleh kepala daerah merupakan salah satu kunci suksesnya pembangunan di daerah. Tanpa adanya inovasi di daerah, pembangunan hanya akan berjalan di tempat. Dengan inovasi maka kepala daerah juga mampu menggerakkan dan mengorganisir masyarakatnya. Di sisi lain inovasi akan membuat penyerapan anggaran di daerah tidak saja untuk pos-pos rutin semata, sehingga fokus pada inovasi sangat penting. Jangan sampai penyerapan anggaran hanya dialokasikan untuk program rutin tanpa ada inovasi daerah yang muncul (Solehudin, 2017).

Deputi Pengembangan Regional Kementerian Perencanaan Pembangunan Nasional (PPN) Arifin Rudiyanto menyatakan bahwa ada delapan faktor yang mempengaruhi perkembangan inovasi di daerah yakni regulasi, kolaborasi, perencanaan daerah, kepemimpinan daerah, kelembagaan inovasi dan roadmap ke depan, anggaran, ketersediaan infrastruktur, serta kualitas dan kuantitas daerah (Setyowati, 2017).Pada 14 September 2017, Presiden Joko Widodo telah menandatangani Peraturan Pemerintah No. 38 Tahun 2017 tentang Inovasi Daerah sebagai pelaksanaan ketentuan Pasal 390 Undang-Undang Nomor 23 Tahun 2014 tentang Pemerintahan Daerah. Menurut PPini, Inovasi Daerah bertujuan untuk meningkatkan kinerja penyelenggaraan Pemerintahan Daerah. Untuk mencapai tujuan sebagaimana dimaksud, maka sasaran inovasi daerah diarahkan untuk mempercepat terwujudnya kesejahteraan masyarakat melalui: a. peningkatan pelayanan publik; b. pemberdayaan dan peran serta masyarakat; dan c. peningkatan daya saing (Sekretariat Kabinet, 2017).

Salah satu daerah yang sukses dengan inovasi daerahnya adalah Kabupaten Banyuwangi dengan program pengembangan desa "Smart Kampung”. Program ini mendesain desa mempunyai kerangka program terintegrasi yang memadukan antara penggunaan TIK berbasis serat optik, kegiatan ekonomi produktif, kegiatan ekonomi kreatif, peningkatan pendidikan-kesehatan, dan upaya pengentasan kemiskinan. Ada tujuh kriteria sehingga desa masuk kriteria Smart Kampung, yaitu pelayanan publik, pemberdayaan ekonomi, pelayanan kesehatan, pengembangan pendidikan dan seni-budaya, peningkatan kapasitas SDM, integrasi pengentasan kemiskinan, dan informasi hukum. Semua kriteria tersebut diturunkan ke program yang menyentuh kepentingan publik (Akmal, 2017).

Bagaimana dengan Kota Samarinda? Dengan visi “Terwujudnya Kota Samarinda sebagai kota metropolitan berbasis industri, perdagangan dan jasa yang maju, berwawasan lingkungan, serta mempunyai keunggulan daya saing untuk meningkatkan kesejahteraan masyarakat”, Kota Samarinda telah tumbuh berkembang tidak hanya menjadi pusat pemerintahan, tapi juga pusat pertumbuhan ekonomi, politik, bisnis, hiburan, perdagangan, serta pendidikan. Segudang permasalahan tata kelola kota dan permasalahan sosial membuat jalannya roda pemerintahan tersendat-sendat. Untuk dapat bersaing dengan daerah lain, maka Kota Samarinda harus memiliki kemauan dan keberanian untuk keluar dari comfort zone menuju creative dan competitive zone. Inovasi harus dijadikan agenda bersama, yang harus menjadi gerakan serentak oleh seluruh komponen. Inovasi harus menjadi pemikiran dan hasil kreasi bersama, harus dirawat secara terus menerus dan menjadi tanggung jawab bersama dengan perangkat daerah yang membidangi penelitian dan litbang 
yang menjadi leading sectorinovasi daerah sehingga kemanfaatannya bisa dirasakan oleh para stakeholders, termasuk masyarakat luas.(LAN, 2016).

Kesuksesan Laboratorium inovasi pada tahun 2016 merupakan modal besar untuk kelanjutaninovasi di lingkungan Pemerintah Kota Samarinda. Jika sebelum berlakunya PP No. 38 Tahun 2017, leading sector inovasi tidak tersebut dengan jelas siapa OPD-nya, maka pasca terbit PP No. 38 Tahun 2017 secara eksplisit disebutkan bahwa inisiatif inovasi daerah dikoordinasikan oleh Kepala Perangkat Daerah yang membidangi penelitian dan pengembangan. Secara regulasi, pembentukan Badan Penelitian dan Pengembangan Daerah (Balitbangda) Kota Samarinda, diakomodasi melalui Peraturan Daerah No. 4 Tahun 2016 tentang Pembentukan dan Susunan Perangkat Daerah serta Peraturan Walikota Samarinda No. 54 Tahun 2016 Tentang Susunan Organisasi dan Tata Kerja Badan Penelitian dan Pengembangan Kota samarinda. Dua peraturan tersebut tentu akan menjadi payung dan panduan Badan Penelitian dan Pengembangan dalam menjalankan segala tugas berkaitan dengan inovasi daerah.

Secara aturan (kelembagaan) memang sudah tersebut dengan jelas dan terperinci mengenai bidang dan seksi yang mempunyai kewenangan berkaitan dengan inovasi, namun demikian, modal kelembagaan saja bagi Balitbangda tidak cukup, karena tak dapat dipungkiribahwa mewujudkan inovasi daerah dengan segala implikasinya merupakan pekerjaan besar. Dari proses perencanaan, pelaksanaan hingga evaluasi,Badan Penelitian dan Pengembanganyang dituntut harus terlibat aktifharus didukung juga dengan sumber daya lainnya seperti sumber daya manusia, anggaran serta sarana dan prasarana. Perubahan kondisi tersebut merupakan lompatan besar bagi Badan Penelitian dan Pengembangan Daerah. Dengan karakteristik pekerjaan sebelumnya yang eksklusif (lebih fokus pada penelitian semata), tiba-tiba harus berubah harus bersifat inklusif. Perubahan kondisi tersebut tentu bukan hal yang mudah untuk dilakukan, perlu komitmen dan strategi untuk bisa beradaptasi terhadap karakteristik barutersebut.

Tuntutan pelaksanaan inovasi daerah yang begitu masif, akan memaksa Balitbangda manapun untuk berlari kencang dalam proses mewujudkan inovasi di daerahnya masing-masing, termasuk Balitbangda Kota Samarinda. Semua pihak tentu berharap atas upaya transformasi Balitbangda Kota Samarindadalam mengatasi berbagai persoalan daerah (seperti pelayanan publik) melalui inovasi daerah. Balitbangda harus berani meninggalkan comfort zone dan bussiness as usual. Balitbangda Kota Samarinda harus tampil menjadi pioneer perubahan dalam penyelenggaraan inovasi sektor publik. Jika peran Balitbangda Kota Samarinda yang begitu besar sebagai leading sectorinovasi tidak segera direspon, maka, dikhawatirkan akan dapat menghambat keseluruhan proses inovasi di Kota Samarinda. Tulisan ini mencoba untuk melakukan analisis terhadap segala upaya penguatan yang harus dilakukan Balitbangda Kota Samarinda sebagai sebuah organisasi pasca penerapan PP No. 38 Tahun 2017 tentang Inovasi Daerah.

\section{B. METODE PENELITIAN}

Penelitian ini merupakan jenis penelitian kualitatifdeskriptif yang bertujuan untuk menggambarkan atau menginformasikan sesuatu (Istijanto, 2005:20).Adapunyang akan dideskripsikan adalah kondisi Badan Penelitian dan Pengembangan Kota Samarinda pasca penerapan PP No. 38 Tahun 2017. Analisis data dilakukan secara kualitatif yang bersifat memaparkan hasil temuan secara mendalam melalui pendekatan nonstatistik (Istijanto, 2005:85). Pengambilan data dilakukan dengan studi kepustakaan terhadap berbagai peraturan perundangan dan dokumen kerja pemerintahan daerah.Adapun fokus dari penelitian ini adalah telaah kebijakan regulasi dengan lahirnya Peraturan Pemerintah No. 38 Tahun 2017 tentang inovasi daerah sebagai sumbang pemikiran bagi penguatan 
peran Perangkat Daerah yang membidangi Inovasi Daerah. Sementara lokus dari penelitian ini Badan Penelitian dan Pengembangan Kota Samarinda.

\section{KERANGKA KONSEP}

\section{BalitbangdaDan Inovasi}

Salah satu peran besar Balitbangda pasca berlakunya PP No. 38 Tahun 2017 adalah berkaitan denganInovasi daerah.Inovasi menurut Makmur dan Rohana Tahier (2015: 9) didefinisikan sebagai suatu proses kegiatan atau pemikiran manusia untuk menemukan sesuatu yang baru berkaitan dengan input, proses dan output , serta dapat memberikan manfaat pada manusia.

Inovasi,menurut Drucker (2017:21),adalah suatu alat untuk memanfaatkan perubahan sebagai peluang bagi usaha yang berbeda atau jasa yang berbeda . inovasi dapat ditampilkan sebagai ilmu, dapat dipelajari dan dapat dipraktekkan. Sedangkan Anthony (2013: 16) mendefinisikan sebagai "sesuatu yang berbeda yang berdampak".

Inovasi adalah keberhasilan ekonomi yang ditimbulkan karena adanya upaya pengenalan terhadapcara baru dan kombinasi baru dari cara-cara lama dalam mentransformasi input menjadi output yang menghasilkan perubahan besar atau drastis dalam perbandingan antara nilai guna yang dipersepsikan oleh konsumen atas manfaat suatu produk. Inovasi yang berhasil adalah inovasi yang menciptakan nilai lebih besar untuk konsumen, untuk komunitas dan lingkungan pada saat yang sama (Fontana, $2011: 18$ ).

Adapun mengenai faktor-faktor organisasional yang berpengaruh terhadap budaya inovasi, Lynne Maher dalam presentasinya berjudul “Creating the Culture of Innovation” (NHS Institute for Innovation and Improvement) menyebutkan adanya tujuh faktor penting yang berpengaruh pada budaya inovasi meliputi pengambilan resiko (risk taking), sumber daya (resources), pengetahuan (knowledge), tujuan (goals), penghargaan (rewards), alat/sarana (tools), serta hubungan (relationship) (Utomo, 2017: 36).

Inovasi memiliki siklus atau tahapan dari inisiasi hingga implementasinya. Rangkaian tahapan yang saling berkaitan dalam mengelola inovasi ini yang dinamakan sebagai manajemen inovasi. Sebagai sebuah ilmu dan seni, maka manajemen inovasi bukanlah sesuatu yang hanya terjadi sekali dan selesai (einmalig, peacemeal, linier), yang terjadi tiba-tiba tanpa upaya sistematis untuk merencanakan, menganalisis, memonitor, mengembangkan dan seterusnya. Inovasi adalah bidang ilmu yang membutuhkan piranti metodologi tertentu, sesederhana apapun (Utomo, 2017: 127).

Organisasi akan belajar jika proses pembaharuan dan perbaikan itu meluas dan menjadi bagian dari cara kita melakukan hal-hal di sini. Norma-norma baru harus dikomunikasikan dan dipahami di seluruh organisasi. Banyak perhatian ditujukan pada kebutuhan organisasi untuk menyesuaikan diri dengan perubahan keadaan. Adalah populer menekankan pentingnya perubahan tanpa mengakui kebutuhan akan pemeliharaan dan stabilitas sistem. Setiap organisasi harus dapat mempertahankan cukup stabilitas untuk dapat berfungsi dengan memuaskan, tetapi tidak membiarkan dirinya menjadi statis, sangat kolot, atau melalaikan kebutuhan akan penyesuaian dengan perubahan keadaan. Pandangan yang realistis mengenai perubahan organisasi dengan mengakui bahwa stabilitas dan penyesuaian diri (adaptation) itu sangat penting untuk kelangsungan hidup (survival) dan pertumbuhan. Oleh karena itu, perlu kesadaran untuk mempelajari bagaimana menyusun, menyesuaikan diri, dan mengubah organisasi dengan cara yang lebih cocok dengan aspirasi manusia. Bagaimana mengorganisir usaha manusia secara efektif ke dalam struktur khusus yang kompleks dalam lingkungan yang berubah dengan cepat, sementara tetap mempertahankan integritas sistem, merupakan perhatian utama dalam zaman kita (Kast dan Rosenzweig, 2007: 840-892). 
Kegiatan pengorganisasian tidak pernah berakhir. Melihat sebuah organisasi sebagai ‘jaringan kerja' (network) pusat-pusat komunikasi pengambilan keputusan yang dapat menghasilkan usahausaha kelompok secara efektif dari usaha-usaha perorangan sehingga terlihat bahwa pengorganisasian bersifat dinamis. Sebuah organisasi harus siap menghadapi perubahan-perubahan identitas dan lingkungannya juga berubah. Empat sebab utama dari dinamika organisasi ialah :

1. Di dalam sebuah organisasi terdapat berbagai variabel dengan saling ketergantungan dan masingmasing dipengaruhi oleh efek-efek kolektif yang mempertahankan variabel-variabel tersebut. Struktur organisasi dibangun di atasnya dan berbagai unit kerja yang berhubungan memiliki ketergantungan secara timbal balik. Pelaksanaan kegiatan ditentukan oleh elemen-elemen manusia yang mengerjakannya.

2. Pengaruh yang terdapat di dalam diri pegawai. Manusia berubah sikapnya, kemampuan dan kepentingannya tidak tetap. Sebagian daripada perilaku tersebut bersifat normal dan didukung oleh program pengembangan. Selanjutnya, pegawai dialih tugaskan, mendapatkan promosi, dipindahkan, menikah, menjadi tua, mengundurkan diri dan meninggal dunia.

3. Pertimbangan-pertimbangan ekonomis, pertumbuhan dan hambatan-hambatan. Tidak diragukan lagi, berbagai perubahan organisasi bertujuan untuk menyempurnakan efektivitasnya. Pekerjaanpekerjaan yang bersifat ganda, pegawai-pegawai yang tidak memiliki pengalaman dan tidak terlatih khusus serta pemborosan biaya, merupakan beberapa diantara sekian banyak sebab yang merubah suatu organisasi.

4. Perubahan-perubahan teknologi. Perkembangan baru dalam bidang teknologi memberikan sumbangan-sumbangan penting kepada dinamika organisasi bahan-bahan baku dan prosesproses baru membutuhkan kegiatan dan unit-unit organisasi baru pula. Misalnya proses-proses produksi otomatis memperkecil fungsi dan sistem produksi lama, sehingga peralatannya perlu diganti (Terry, 2016:121-123).

\section{Studi Peraturan Perundangan}

Dengan pertimbangan bahwa penyelenggaraan pemerintahan daerah diarahkan untuk mempercepat terwujudnya kesejahteraan masyarakat melalui peningkatan pelayanan, pemberdayaan, dan peran serta masyarakat, serta peningkatan daya saing daerah dengan memperhatikan prinsip demokrasi, pemerataan, keadilan, dan kekhasan suatu daerah dalam Sistem Negara Kesatuan Republik Indonesia, maka diterbitkanlah Undang-Undang 23 Tahun 2014 yang merupakan pengganti Undang-Undang 32 Tahun 2004 tentang Pemerintahan Daerah. Pada dasarnya perubahan UndangUndang Nomor 32 Tahun 2004 ditujukan untuk mendorong lebih terciptanya daya guna dan hasil guna penyelenggaraan Pemerintahan Daerah dalam menyejahterakan masyarakat, baik melalui peningkatan pelayanan publik maupun melalui peningkatan daya saing Daerah. Perubahan ini bertujuan untuk memacu sinergi dalam berbagai aspek dalam penyelenggaraan Pemerintahan Daerah dengan Pemerintah Pusat.Kekuasaan Pemerintahan sebagaimana dimaksud pada Pasal 5 ayat (1) UndangUndang 23 Tahun 2014, diuraikan dalam berbagai Urusan Pemerintahan. Urusan Pemerintahan terdiri atas urusan pemerintahan absolut, urusan pemerintahan konkuren, dan urusan pemerintahan umum. Unsur penunjang Urusan Pemerintahan yang menjadi kewenangan Daerah meliputi: a) perencanaan; b) keuangan; c) kepegawaian serta pendidikan dan pelatihan; d) penelitian dan pengembangan; dan e) fungsi lain sesuai dengan ketentuan peraturan perundang-undangan.

Menurut Peraturan pemerintah No. 18 tahun 2016 tentang Perangkat Daerah, yang merupakan peraturan turunan dari Undang-undang 23 Tahun 2014 menyatakan bahwa pembentukan perangkat daerah dilakukan berdasarkan asas: a) Urusan Pemerintahan yang menjadi kewenangan daerah; b) intensitas urusan pemerintahan dan potensi daerah; c) efisiensi; d) efektivitas; e) pembagian habis 
tugas; f) rentang kendali; g) tata kerja yang jelas; dan h) fleksibilitas. Dalam Undang-Undang 23 Tahun 2014 maupun Peraturan Pemerintah No. 18 tahun 2016 disebutkan bahwa unsur penelitian dan pengembangan merupakan salah satu unsur Penunjang Urusan Pemerintahan yang diwadahi dalam perangkat daerah berupa Badan Daerah yang merupakan unsur penunjang yang melaksanakan fungsi-fungsi yang bersifat strategis yang diperlukan untuk mendukung pelaksanaan urusan pemerintahan yang menjadi kewenangan daerah antara lain perencanaan, pengawasan, kepegawaian, keuangan, pendidikan dan latihan serta penelitian dan pengembangan.

Majunya suatu bangsa sangat ditentukan oleh inovasi yang dilakukan bangsa tersebut. Untuk itu maka diperlukan adanya perlindungan terhadap kegiatan yang bersifat inovatif yang dilakukan oleh aparatur sipil negara di daerah dalam memajukan daerahnya. Perlu adanya upaya memacu kreativitas daerah untuk meningkatkan daya saing daerah. Untuk itu perlu adanya kriteria yang obyektif yang dapat dijadikan pegangan bagi pejabat Daerah untuk melakukan kegiatan yang bersifat inovatif. Dengan cara tersebut inovasi akan terpacu dan berkembang tanpa ada kekhawatiran menjadi obyek pelanggaran hukum.Pada Pasal 386Undang-Undang 23 Tahun 2014 disebutkan bahwa dalam rangka peningkatan kinerja penyelenggaraan Pemerintahan Daerah, Pemerintah Daerah dapat melakukan inovasi. Inovasi yang dimaksud adalah semua bentuk pembaharuan dalam penyelenggaraan pemerintahan daerah. Selanjutnya dalam Pasal 387 disebutkan bahwa dalam merumuskan kebijakan inovasi, pemerintahan daerah mengacu pada prinsip:

a. peningkatan efisiensi;

b. perbaikan efektivitas;

c. perbaikan kualitas pelayanan;

d. tidak ada konflik kepentingan;

e. berorientasi kepada kepentingan umum;

f. dilakukan secara terbuka;

g. memenuhi nilai-nilai kepatutan; dan

h. dapat dipertanggungjawabkan hasilnya tidak untuk kepentingan diri sendiri

Pemerintah pusat melakukan penilaian terhadap inovasi yang dilaksanakan oleh pemerintah daerah. Dalam melakukan penilaian terhadap inovasi daerah, pemerintah pusat memanfaatkan lembaga yang berkaitan dengan penelitian dan pengembangan.Untuk melaksanakan ketentuan Pasal 390 Undang-Undang Nomor 23 Tahun $2 \mathrm{Ol} 4$ tentang Pemerintahan Daerah, maka pemerintah kemudian menetapkan Peraturan Pemerintah tentang Inovasi Daerah yang tertuang dalam Peraturan Pemerintah No. 38 Tahun 2017. Dalam Peraturan Pemerintah tersebut, dijelaskan bahwa inovasi daerah adalah semua bentuk pembaharuan dalam penyelenggaraan pemerintahan daerah. Inovasi daerah bertujuan untuk meningkatkan kinerja penyelenggaraan pemerintahan daerah. Untuk mencapai tujuan tersebut, sasaran inovasi daerah diarahkan untuk mempercepat terwujudnya kesejahteraan masyarakat melalui peningkatan pelayanan publik, pemberdayaan dan peran serta masyarakat, serta peningkatan daya saing Daerah. Inovasi Daerah diselenggarakan berdasarkan prinsip peningkatan efisiensi, perbaikan efektivitas, perbaikan kualitas pelayanan, tidak menimbulkan konflik kepentingan, berorientasi kepada kepentingan umum, dilakukan secara terbuka, memenuhi nilai kepatutan, dan dapat dipertanggungiawabkan hasilnya tidak untuk kepentingan diri sendiri.

Jika dilihat dari bentuknya, inovasi daerah menurut Peraturan Pemerintah ini terbagi menjadi 3, yaitu:

a. Inovasi Tata Kelola Pemerintahan Daerah, merupakan inovasi dalam pelaksanaan manajemen pemerintahan daerah yang meliputi tata laksana internal dalam pelaksanaan fungsi manajemen dan pengelolaan unsur manajemen 
b. Inovasi Pelayanan Publik, merupakan inovasi dalam penyediaan pelayanan kepada masyarakat yang meliputi proses pemberian pelayanan barang/jasa publik dan inovasi jenis dan bentuk barang/jasa publik

c. Inovasi Daerah lainnya sesuai dengan urusan pemerintahan yang menjadi kewenangan daerah, merupakan segala bentuk inovasi dalam penyelenggaraan urusan pemerintahan yang menjadi kewenangan pemerintah daerah.

Adapun Kriteria Inovasi Daerah menurut Pasal 6 meliputi:

a. mengandung pembaharuan seluruh atau sebagian unsur dari inovasi

b. memberi manfaat bagi Daerah danf atau masyarakat

c. tidak mengakibatkan pembebanan dan/atau pembatasan pada masyarakat yang tidak sesuai dengan ketentuan peraturan perlindang-undangan

d. merupakan Urusan Pemerintahan yang menjadi kewenangan Daerah

e. dapat direplikasi

Inisiatif sebagaimana dimaksud dalam PP ini dilengkapi dengan proposal Inovasi Daerah yang sekurang-kurangnya memuat: a. bentuk Inovasi Daerah; b. rancang bangun Inovasi Daerah dan pokok perubahan yang akan dilakukan; c. tujuan Inovasi Daerah; d. manfaat yang diperoleh; e. waktu uji coba Inovasi Daerah; dan f. anggaran, jika diperlukan.Pasal 8 menyatakan bahwa Inisiatif Inovasi Daerah yang berasal dari Kepala Daerah dibahas oleh tim independen dikoordinasikan oleh kepala Perangkat Daerah yang membidangi penelitian dan pengembangan. Pasal 9 menyatakan bahwa Inisiatif Inovasi Daerah yang berasal dari anggota DPRD yang dituangkan dalam proposal Inovasi Daerah dibahas dan ditetapkan layak dalam rapat paripurna DPRD disampaikan kepada Kepala Daerah dan selanjutnya Perangkat Daerah yang membidangi penelitian dan pengembangan melakukan verifikasi kesesuaian proposal dengan kriteria Inovasi Daerah. Pasal 10 menyatakan bahwa Inisiatif Inovasi Daerah yang berasal dari ASN yang mendapat ijin tertulis dari Kepala Perangkat Daerahnya diserahkan ke Perangkat Daerah yang membidangi penelitian dan pengembangan disertai dengan proposal Inovasi Daerah untuk dievaluasi. Kepala Perangkat Daerah yang membidangi penelitian dan pengembangan menyampaikan inisiatif Inovasi Daerah kepada kepala Daerah.

Pasal 11 menyatakan bahwa Inisiatif Inovasi Daerah yang berasal dari Perangkat Daerah disampaikan kepada Perangkat Daerah yang membidangi penelitian dan pengembangan disertai dengan proposal Inovasi Daerah untuk dievaluasi. Pasal 12 menyatakan bahwa Inisiatif Inovasi Daerah yang berasal dari anggota masyarakat disampaikan kepada ketua DPRD dan/atau kepala Daerah disertai dengan proposal Inovasi Daerah dievaluasi oleh Perangkat Daerah yang membidangi penelitian dan Pengembangan. Pada Pasal 13, Dalam melakukan evaluasi terhadap inisiatif Inovasi Daerah, Perangkat Daerah yang membidangi penelitian dan pengembangan dapat melibatkan perguruan tinggi, pakar, dan atau praktisi.

Peraturan Daerah Kota Samarinda Nomor 4 Tahun 2016 Tentang Pembentukan dan Susunan Perangkat daerah Kota Samarinda. Pasal 3 ayat (6) : Badan Daerah sebagaimana dimaksud pada ayat (1) huruf e terdiri atas : Badan Penelitian dan Pengembangan Tipe B melaksanakan fungsi penunjang penelitian dan pengembangan (Perda No.4 Tahun 2016). Peraturan Walikota Samarinda Nomor 54 Tahun 2016 Tentang Susunan Organisasi dan tata Kerja Badan Penelitian dan Pengembangan Daerah Kota Samarinda. Pasal 2 Susunan Organisasi terdiri atas : 
a. Kepala

b. Sekretariat membawahkan :

1) Sub Bagian Perencanaan Program dan Keuangan; dan

2) Sub Bagian Umum dan Kepegawaian

c. Bidang Penelitian dan Pengembangan Pemerintahan, Sosial dan Budaya

1) Sub Bidang Penyelenggaraan Pemerintahan, data dan pengkajian peraturan

2) Sub Bidang Sosial;dan

3) Sub Bidang Budaya dan Kominfo

d. Bidang Penelitian dan Pengembangan Inovasi dan Teknologi, membawakan :

1) Sub Bidang Pengembangan Teknologi dan Inovasi;

2) Sub Bidang Difusi Inovasi dan penerapan teknologi; dan

3) Sub Bidang Diseminasi kepenelitian dan pengembangan

e. Bidang Penelitian dan pengembangan Ekonomi, Pembangunan dan Sumber daya Alam(SDA), membawahkan:

1) Sub Bidang Ekonomi

2) Sub Bidang Pembangunan

3) Sub Bidang SDA Masyarakat

f. Kelompok jabatan Fungsional,dan

g. UPT (Perwali No. 54 Tahun 2016)

Pasal 3 ayat (1) : badan sebagaimana dimaksud dalam pasal 2 huruf a mempunyai tugas membantu Walikota melaksanakan urusan pemerintahan konkuren bidang penelitian dan pengembangan yang meliputi penelitian dan pengembangan pemerintahan pembangunan pengkajian peraturan, penelitian dan pengembangan inovasi dan teknologi dan penelitian dan pengembangan sosial kependudukan (Perwali No. 54 Tahun 2016).Pada Pasal 4 disebutkan bahwa untuk menyelenggarakan tugas sebagaimana dimaksud dalam Pasal 3 Ayat (1) Badan mempunyai fungsi:

a. Penyusunan kebijakan teknis di bidang penelitian dan pengembangan

b. Pelaksanaan tugas dukungan teknis di bidang penelitian dan pengembangan

c. Pemantauan, evaluasi dan pelaporan pelaksanaan tugas di bidang penelitian dan pengembangan

d. Pembinaan teknis penyelenggaraan fungsi penunjang urusan pemerintahan di bidang penelitian dan pengembangan, dan

e. Pelaksanaan fungsi lain yang diberikan oleh Walikota sesuai dengan tugas dan fungsi (Perwali No. 54 Tahun 2016)

Pasal 14 menyebutkan bahwa Bidang Penelitian dan Pengembangan Inovasi dan Teknologi mempunyai tugas melaksanakan perumusan dan pelaksanaan kebijakan, pemberian bimbingan teknis dan supervisi, serta pemantauan, evaluasi dan pelaporan di Bidang Inovasi dan Teknologi dipimpin oleh Kepala Bidang yang berada di bawah dan bertanggung jawab langsung kepada Kepala Badan.

\section{HASIL DAN PEMBAHASAN}

\section{Persandingan dan Keterkaitan peraturan perundangan dengan Renstra Badan Penelitian dan Pengembangan}

Berdasarkan Peraturan Pemerintah No. 38 Tahun 2017 dapat dianalisis beberapa fungsi Balitbangda Kota samarinda dalam upaya penguatan kelembagaan Badan Penelitian dan Pengembangan Kota Samarinda sebagai berikut: 
1. Pemberi input terhadap kriteria inovasi daerah (Pasal 6) : Pada fungsi ini Balitbangda harus mempunyai pemahaman yang baik mengenai apa itu inovasi dengan berbagai kriterianya.Kriteria dasar yang harus dimengerti antara lain : kualifikasi pembaharuan, kemanfaatan bagi daerah dan masyarakat serta kemampuan memperhitungkan terhadap kegiatanreplikasi. Dengan pemahaman tersebut, dapat dijadikan modal bagi Balitbangdauntuk melakukan evaluasi terhadap berbagai proses inovasi lainnya. Kemanfaatan sebagaimana penjelasan PP No. 38 Tahun 2017 berkaitan dengan kemampuan analisa untuk melakukan perhitungan bahwa inovasi dapat menambah pendapatan asli daerah, menghemat belanja daerah, meningkatkan capaian kinerja Pemerintah Daerah, meningkatkan mutuPelayanan Publik. Berdasarkan tuntutan ini, Badan Penelitian dan Pengembangan harus dapat melakukan proses kuantisi yang baik (walaupun bersifat umum) untuk menyikapi sebuah produk inovasi berdasarkan analisa, apakah produk inovasi yang akan dibuat dan diterapkan oleh Inovator berpotensi menghemat penggunaan APBD (bahkan berpotensi menambah APBD), atau justru sebaiknya, hanya akan menjadi sumber permasalahan keuangan karena menimbulkan in-efisiensi. Untuk itu Badan Penelitian dan Pengembangan perlu disupport dengan SDM yang dapat melakukan analisa perhitungan dengan baik.

Berkaitan dengan kriteria replikasi, yang perlu diperhatikan oleh Balitbangda,replikasiinovasi yang akan dilakukan harus dipastikan adaptif untuk diterapkan ataukah tidak, karena dibutuhkan penyesuaian-penyesuain yang significant, seperti berkaitan dengan ketersediaan SDM, finansial, kelembagaan, saparas yang ada, dengan kata lain Badan Penelitian dan Pengembangan harus mempunyai kemampuan penghitungan yang cermat terkait faktor pendukung dan penghambat dari sebuah replikasi yang akan diambil dan diterapkan

2. Koordinator Tim Independen atas inisiatif Inovasi daerah yang berasal dari Kepala Daerah (Pasal 8) : Untuk menjalankan tugas ini, Balitbangda harus memiliki kemampuan koordinatif,denganmemiliki daya komunikasi yang baik sehingga dapat memperlancar pelaksanaan koordinasi yang harus dilakukan.

3. Menjembatani Inisiatif Inovasi Daerah yang berasal dari anggota DPRD (Pasal 9) : Dalam menjalankan tugas ini, Balitbangda harus mampu melakukan verifikasi dengan baik dan cermat terhadap kesesuaian proposal setelah diterima oleh Kepala Daerah berdasarkan kriteria Inovasi Daerah (mengandung pembaharuan,bermanfaat, tidak mengakibatkan pembebanan yang tidak sesuai peraturan, merupakan urusan pemerintah berdasar kewenangan dan dapat direplikasi).

4. Menjembatani Inisiatif Inovasi Daerah yang berasal dari ASN (Pasal 10) : Dalam menjalankan tugas ini, Balitbangda harus mampu melakukan evaluasi atas proposal Inovasi Daerah dari ASN yang telah mendapatkan izin tertulis. Dalam menjalankan tugas iniBalitbangdadituntut untuk memiliki kemampuanfasilitasi guna menyampaikan inisiatif inovasi tersebut kepada Kepala daerah jika memang hasil evaluasi dapat dibuktikan bahwa inovasi tersebut layak dan sesuai dengan kriteria.

5. Menjembatani Inisiatif Inovasi Daerah yang berasal dari Perangkat Daerah (Pasal 11) : Dalam menjalankan tugas ini, Balitbangdaharus memiliki kemampuanuntuk melakukan evaluasi dengan baik guna menindak lanjuti proposal Inovasi Daerah yang telah diterima, sekaligus memfasilitasi untuk menyampaikan inovasi dari perangkat daerah kepada Kepala Daerah jika inovasi tersebut layak dan sesuai dengan kriteria.

6. Menjembatani inisiatif Inovasi Daerah yang berasal dari anggota masyarakat (Pasal 12): Dalam hal ini, disamping Balitbangda harus memiliki kemampuan melakukan evaluasi atas inistiatif inovasi, obyektivitas juga harus bisa dijaga oleh Balitbangda untuk bersikap secara proporsional dalam menyikapi inovasi yang berasal dari masyarakat, baik yang disampaikan kepada Ketua DPRD maupun kepada Kepala Daerah). 
7. Pelaksanaan fungsi Evaluator (Pasal 13): Balitbangda harus memiliki kemampuan untuk berpikir dan bekerja cepat. Hal ini dikarenakan, waktu untuk evalusi terhadap inisiatif inovasi paling lama 10 (sepuluh) hari kerja. Dijelaskan lebih lanjut, dalam melakukan evaluasi terhadap inisiatif Inovasi Daerah, Perangkat Daerah yang membidangi penelitian dan pengembangan dapat melibatkan perguruan tinggi, pakar, dan atau praktisi. Dengan melibatkan perguruan tinggi, pakar, dan atau praktisi, maka, pemahaman atas proses kerjasama secara konsep dan teknis perlu dipahami. Balitbangda harus bisa melakukan mapping terhadap perguruan tinggi, pakar dan praktisi yang akan dilibatkan sebagai mitra serta bagaimana menentukannya dalam sistem penganggaran.

8. Menerima laporan secara berkala mengenai pelaksanaan uji coba inovasi daerah (Pasal 16) : Dalam menjalankan kegiatan ini, dapat dilakukan dengan metode jemput bola, karena jika hanya pasif (menunggu laporan masuk), kecil kemungkinannya para inovator melaporkan segala proses inovasinya secara berkala. Dengan metode jemput bola, laporan yang didapat akan lebih lengkap informasinya.

9. Menerima laporan uji coba inovasi daerah yang tidak berhasil dan dihentikan pelaksanaannya (Pasal 17): Hasil laporan uji coba inovasi daerah yang tidak berhasil dan dihentikan pelaksanaannya harus disampaikan kepada kepala Daerah

10. Menerima hasil pelaksanaan seluruh tahapan uji coba inovasi, Melakukan evaluasi menyeluruh terhadap hasil tahapan pelaksanaan uji coba inovasi daerah, Menyampaikan hasil evaluasi kepada Kepala Daerah, Kepala Badan Penelitian dan Pengembangan berperan sebagai pemberi masukan utama Kepala Daerah dalam hal inovasi (Pasal 18) : Untuk menunjang segala proses tersebut, yang harus diperhatikan oleh Balitbangda adalah: database yang dimiliki harus baikserta harus ada analisa yang kuat di dalamnya. Tidak ada penyebutan secara jelas di dalam PP bahwa segala proses yang dilakukan oleh Balitbangda terkait inovasi harus melalui Sekda, hal ini mengindikasikan bagaimana kuatnya posisi Balitbangdadalam melaksanakan tugasnya secara lebih independen.

Peran Balitbangda yang begitu penting sebagai koordinator dalam pelaksanaan inovasi daerah, tidak saja tersebut di dalam PP No. 38 Tahun 2017, tapi juga tersebut di peaturan lainnya, yakni peraturan Peraturan Bersama Menteri Negara Riset Dan Teknologi Republik Indonesia Dan Menteri Dalam Negeri Republik Indonesia Nomor: 03 Tahun 2012 Nomor: 36 Tahun 2012 Tentang Penguatan Sistem Inovasi Daerah, khususnya pada Pasal 5 (3) menyebutkan bahwa Tim Koordinasi Kabupaten/ Kota melakukan koordinasi paling sedikit satu kali dalam satu tahun atau sesuai kebutuhan, Badan Penelitian dan Pengembangan berperan sebagai Koordinator Tim Independen atas inisiatif Inovasi daerah.

Begitu pentingnya peran Balitbangda sebagai leading inovasi di daerah, Peraturan Bersama Menteri Negara Riset Dan Teknologi Republik Indonesia dan Menteri Dalam Negeri Republik Indonesia Nomor: 03 Tahun 2012 Nomor: 36 telah memberikan beberapa petunjuk tentang apa yang harus dilakukan oleh Balitbangda dalam menjalankan tugasnya. Berikut petunjuk tersebut sebagaimana tabel analisis di bawah ini: 
Tabel 1.

Analisis Petunjuk Bagi Balitbangda Dalam Menjalankan Fungsi Sebagai Leading Inovasi Berdasarkan Peraturan Bersama Menteri Negara Riset Dan Teknologi Republik Indonesia Dan Menteri Dalam Negeri Republik Indonesia Nomor: 03 Tahun 2012 Nomor: 36 Tahun 2012

\begin{tabular}{|c|c|c|}
\hline Pasal & Peranan & Analisis \\
\hline Pasal 15 & Nilai Budaya & $\begin{array}{l}\text { Kelembagaan yang kuat, Kuantitas dan } \\
\text { kualitas SDM yang bagus, jika tidak } \\
\text { dilindungi dengan nilai budaya yang } \\
\text { positif dalam pelaksanaan tugasnya, } \\
\text { perlahan tapi pasti potensi-potensi besar } \\
\text { tersebut akan terkikis dan melemah dengan } \\
\text { sendirinya. (3) Norma/etika/budaya } \\
\text { sebagaimana dimaksud, merupakan nilai- } \\
\text { nilai profesionalisme dalam mendukung } \\
\text { terciptanya kondisi yang kondusif bagi } \\
\text { penguatan SIDa. Yang mana dipengaruhi } \\
\text { oleh risk taking, resources, knowledge, } \\
\text { goals, rewards, dan relationship } \\
\text { sebagaimana dijelaskan dalan bab teori } \\
\text { (Utomo, 2017:36) }\end{array}$ \\
\hline Pasal 16 & $\begin{array}{l}\text { Disamping penataan institusi } \\
\text { pemerintah, dilakukan dengan } \\
\text { cara mensinergikan program dan } \\
\text { kegiatan kementerian dan } \\
\text { lembaga dalam penguatan SIDa, } \\
\text { penataan terhadap Pemda } \\
\text { dilakukan dengan cara : } \\
\text { membentuk Badan Penelitian } \\
\text { dan Pengembangan, } \\
\text { meningkatkan kapasitas dan } \\
\text { peran Badan Penelitian dan } \\
\text { Pengembangan sebaga } \\
\text { koordinator dalam penguatan } \\
\text { SIDa. Lebih lanjut disampaikan } \\
\text { Penataan lembaga kelitbangan } \\
\text { juga dilakukan dengan cara } \\
\text { peningkatan kapasitas dan peran } \\
\text { ilmu pengetahuan dan teknologi. }\end{array}$ & $\begin{array}{l}\text { SIDa, dalam penyusunan dan } \\
\text { pelaksanaannya sangat bergantung pada } \\
\text { upaya koloboratif yang akan dilakukan } \\
\text { oleh Balitbangda. Semakin terpetakan } \\
\text { dengan baik pengelolaan stakeholders } \\
\text { melalui peran dan kontribusinya masing- } \\
\text { masing oleh Balitbangda maka akan } \\
\text { tersinergi upaya terhadap penyusunan dan } \\
\text { penguatannya. Oleh karenanya, menjadi } \\
\text { kebutuhan bagi balitbangda untuk } \\
\text { melakukan perubahan terhadap sifat } \\
\text { kerjanya yang semula lebih tertutup } \\
\text { (terlalu fokus pada pelaksanaan penelitian) } \\
\text { menjadi lebih inklusif sebagaimana } \\
\text { tersebut oleh Terry bahwa dalam sebuah } \\
\text { organisasi terdapat berbagai variabel } \\
\text { dengan saling ketergantungan dan masing- } \\
\text { masing dipengaruhi oleh efek-efek kolektif } \\
\text { yang mempertahankan variabel-variabel } \\
\text { tersebut. Struktur organisasi dibangun di } \\
\text { atasnya dan berbagai unit kerja yang } \\
\text { berhubungan memiliki ketergantungan } \\
\text { secara timbal balik. Pelaksanaan kegiatan } \\
\text { ditentukan oleh elemen-elemen manusia } \\
\text { yang mengerjakannya (Terry, 2016:121- } \\
\text { 123). }\end{array}$ \\
\hline
\end{tabular}




\begin{tabular}{|l|l|l|} 
& $\begin{array}{l}\text { Hal lainnya yang perlu mendapatkan } \\
\text { perhatian berkaitan dengan SDM } \\
\text { adalahmenjaga agar komitmen kinerja } \\
\text { terus terjaga dan Pengaruh yang terdapat di } \\
\text { dalam diri pegawai selalu positif, bukanlah } \\
\text { hal yang mudah. Manusia berubah } \\
\text { sikapnya, kemampuan dan kepentingannya } \\
\text { tidak tetap. Sebagian daripada perilaku } \\
\text { tersebut bersifat normal dan didukung oleh } \\
\text { program pengembangan. Selanjutnya, } \\
\text { pegawai dialih tugaskan, mendapatkan } \\
\text { promosi, dipindahkan, menikah, menjadi } \\
\text { tua, mengundurkan diri dan meninggal } \\
\text { dunia (Terry, 2016:121-123). }\end{array}$ \\
\hline $\begin{array}{l}\text { Pasal 18 } \\
\text { Melakukan penataan terhadap } \\
\text { norma/etika/budaya dengan cara } \\
\text { mengembangkan } \\
\text { profesionalisme dan } \\
\text { menginternalisasikan nilai-nilai } \\
\text { sosial bagi penguatan SIDa. }\end{array}$ & $\begin{array}{l}\text { Sebaik apapun sebuah norma/nilai yang } \\
\text { sudah dirumuskan, hanya akan efektif } \\
\text { pemberlakuannya jika norma/nilai tersebut } \\
\text { diketahui dan dipahami oleh seluruh SDM } \\
\text { organisasi dan para stakeholdersnya. Oleh } \\
\text { karenanya norma-norma yang baru harus } \\
\text { dikomunikasikan dan dipahami di seluruh } \\
\text { organisasi. Tentunya adaptasi juga sangat } \\
\text { diperlukan untuk kelangsungan organisasi. } \\
\text { Hal ini sesuai dengan pendapat (kast dan } \\
\text { Rosenzweig, 2007: 840) }\end{array}$ \\
\hline
\end{tabular}

Dalam menjalankan tugas dan fungsinya, Badan Penelitian dan Pengembangan menetapkan Visi 2016-2021: Terwujudnya Litbang sebagai wadah rumusan kebijakan teknis dan teknologi yang aplikatif, inovatif, komperatif serta berwawasan lingkungan. Dengan karakteristik Balitbang saat ini yang mempunyai fungsi koordinatif di bidang inovasi berdasarkan PP No. 38 Tahun 2017, kata inovatif yang tersebut di dalam visi masih belum cukup merepresentasikan kebutuhan, hal ini dikarenakan kata inovatif dimaksud hanya mengacu secara internal di dalam tubuh Balitbangda sendiri, belum mengakomodasi fungsi koordinatif inovasi di lingkup Pemkot Samarinda. Point koordinatif tersebut harus dapat tergambar jelas dalam Visi Balitbangda, dengan menyebutkannya secara jelas ke dalam Visi, maka akan menjadi patokan perumusan tugas dan fungsi Balitbangda bagi bidang dan subbidang di bawahnya.Pembagian tugas yang dapat terbagi habis akan dapat memaksimalkan fungsi dan tugas dari Balitbangda.

Untuk mewujudkan visi tersebut, misi yang akan dilaksanakan adalah :

1. Mempersiapkan dan menyediakan informasi kegiatan Badan Penelitian dan Pengembangan Kota Samarinda

2. Menyediakan dan mempersiapkan kegiatan Badan Penelitian dan Pengembangan Kota samarinda dalam pembentukan sumber daya

3. Menyediakan informasi dan memanfaatkan hasil penelitian dan pengembangan sebagai input kebijakan pembangunan daerah 
Dari ketiga misi tersebut, belum terlihat jelas misi mengenai inovasi sebagaimana yang tercantum di dalam visi. Kata inovasi yang belum terepresentasikan secara konkrit ke dalam misi, dapat berpotensi menimbulkan hambatan dalam menerapkan proses pencapaian mimpi dan perencanaan. Keberadaan misi akan sangat membantu untuk menjadi kaitan dalam membuat dan menentukan rancangan program dan kegiatan.Oleh karenanya perlu dilakukan review terhadap Visi dan Misi Balitbangda Kota Samarindaagar mampu mencerminkan pelaksanaan tugas dan fungsi berdasarkan peraturan yang baru di bidang inovasi.

Setelah memperhatikan misi, maka yang harus diperhatikan selanjutnya adalah renstra. Di dalam dokumen Renstra Balitbangda Kota Samarinda Tahun 2016-2021,terdapat 4 (empat) dari 7 (tujuh) agenda yang masih relevan dalamkondisi saat ini untuk dijadikan agenda prioritas yang harusdiwujudkan segera, yakni :

1. Pelayanan SDM yang belum Profesional

2. Sarana dan Prasarana yang belum sesuai dengan Kebutuhan Kantor

3. Pengambilan kebijakan teknis masih memberatkan kepentingan politik

4. Keterbatasan Anggaran yang di berikan.

Berkaitan dengan SDM, secara kuantitas, Balitbangda Kota Samarinda didukung oleh pegawai sebanyak 42 orang, terdiri dari 27 orang laki-laki dan 15 orang perempuan.Alokasi penempatan personil berdasarkan bagian / bidang Badan Penelitian dan Pengembangan Daerah Kota Samarinda adalah sebagai berikut:

$\begin{array}{ll}\text { Kepala Badan } & : 1 \text { orang } \\ \text { Sekretariat } & : 21 \text { orang } \\ \text { Bidang Litbang } & : 20 \text { orang } \\ \text { Kelompok Jabatan Fungsional/Widyaiswara } & : \text { - orang } \\ \text { Peneliti } & : \text { - orang }\end{array}$

Sementara, berkaitan dengan latar belakang pendidikan, sebagaimana tersebut di dalam renstra, dapat terlihat dalam tabel di bawah ini :

Tabel 2.

Pendidikan Pegawai Berdasarkan Tingkat Pendidikan Formal

\begin{tabular}{|c|c|c|}
\hline NO & TINGKAT PENDIDIKAN & JUMLAH \\
\hline 1. & S3 & 2 Orang \\
2. & S2 & 12 Orang \\
3. & S1/D4 & 15 Orang \\
4. & D3 & 1 Orang \\
5. & SLTA & 11 Orang \\
6. & SLTP & 1 Orang \\
\hline & JU M L A H & 42 Orang \\
\hline
\end{tabular}

Berkaitan dengan Sumber Daya Manusia(SDM),Balitbangda Kota samarinda harus melakukan pembenahan, baik dari segi kuantitas maupun kualitasnya. Luasnya ruang lingkup pekerjaan yang akan menjadi tugas balitbangda dalam pelaksanaan inovasi daerah harus ditunjang dengan jumlah SDM yang mencukupi dan mempunyai kemampuan analisis, komunikasi dan koordinatif yang baik. 
Jumlah pegawai di Bidang Inovasi yang ada saat inihanya berjumlah 6 orang, dengan jumlah struktural 4 orang. Sehingga Jabatan pelaksana hanya 2 orang. Dengan jumlah tersebut, tentu akan memberatkan langkah balitbangda untuk melakukan fungsi evaluasi dan koordinasi di bidang inovasi, terlebih lagi BalitbangdaKota samrinda belum mempunyaiSDM pengampu Jabatan Fungsional Peneliti yang seharusnya dapat memperkuat Bidang Inovasi dalam melakukan berbagai proses analisis dan evaluasi penyelenggaraan inovasi daerah.

Untuk sarana dan prasarana, Badan Penelitian dan Pengembangan perlu di support terutama yang berkaitan dengan IT, mulai dari jaringannya hingga peralatan operasioanlnya seperti komputer. Penyediaan wifi selama 24 jam yang sudah ada saat ini perlu ditunjang dengan kapasitas bandwidth yang mencukupi karena merupakan modal pelaksanaan otomasi Sistem Inovasi Daerah (SIDa), dan pelaksanaan tugas lainnya yang berbasis sistem. Hal tersebut perlu mendapat komitmen Kepala Daerah, karena segala kebijakan terhadap pemenuhan sarana dan prasana merupakan isu yang sensitif, kondisi ini didasari dari fenomena bahwa perangkat daerah apapun akan selalu merasa kekurangan berkaitan dengan penyediaan sarana dan prasarana. Keterbatasan anggaran pemerintah daerah untuk melakukan belanja modal merupakan embrio dari munculnya fenomena tersebut, terlebih dengan kondisi finansial daerah yang semakin tahun kecenderungannya terus menurun.

Tantangan lain yang juga tersebut di dalam rentra Balitbangda Kota Samarinda dan perlu mendapat perhatian adalah berkaitan denganPengambilan kebijakan teknis yang masih memberatkan kepentingan politik. Inovasi hadir sebagai pintu masukbagi Kota Samarinda untuk mensukseskan masyarakat dan daerah berdasarkan potensi yang dimiliki. Dengan demikian,setiap inovasi yang dihasilkan harus benar-benar berasal dari perhitungan dan analisa keilmuan yang obyektif, yang bebas dari kepentingan siapapun, termasuk kepentingan politik yang terepresentasikan dari sosok kepala daerah serta DPRD. Jika inovasi yang akan dibuat oleh Kepala Daerah ataupun DPRD (menggunakan dana yang besar) tidak lolos dalam proses perhitungan dan analisis untung ruginya, maka harus berani disampaikan untuk dihentikan. Dengan demikian, inovasi yang dirancang dan dihasilkan murni berdasar pada kebutuhan dan potensi daerah.

Adapun berkaitan dengan anggaran Balitbangda Kota Samarinda, besaran anggaran saat ini berdasar Pagu Indikatif Rencana kerja SKPD di lingkungan Pemkot Samarinda Tahun 2017 sebesar Rp. 5. 419.230.000 (Lima Milyar Empat Ratus Sembilan Belas Juta Dua ratus Tiga Puluh Ribu Rupiah) atau 0,087 \% dari total alokasi pagu indikator RKP Kota Samarinda Tahun 2017 sebesar Rp. 6.203.428.754.225(Enam Triliun Dua ratus Tiga Milyar Empat Ratus Dua Puluh Delapan Juta Tujuh Ratus Lima Puluh Empat RibuDua Ratus Dua Puluh Lima Rupiah). Dengan sifat kerja yang sama untuk melakukan koordinasi lintas instansi, pagu anggaran Balitbangda tersebut ternyata masih jauh jumlahnya dengan besaran anggaran Bappeda sebesar Rp. 36.969.174.000 (Tiga Puluh Enam Milyar Sembilan Ratus Enam Puluh Sembilan Juta Seratus Tujuh Puluh Empat Ribu Rupiah) atau senilai0,596 \% dari alokasi pagu indikator RKP Kota Samarinda (Bappeda Kota Samarinda, 2017). Besaran tersebut masih sangat jauh dari daerah lainnyaseperti Kabupaten Pelalawan Prov. Riau yang melakukan penguatan sistem inovasi dengan memberikan porsi yang cukup besar untuk investasi di bidang Litbang yaitu sebesar 2\% dari APBD sebagaimana paparan Taufik (2013) bahwa untuk menjadi salah satu dari 20 kabupaten paling kompetitif di Indonesia tahun 2020 Kabupaten Pelalawan Provinsi Riau melakukan penguatan sistem inovasi dengan memberikan porsi yang cukup besar untuk investasi di bidang Litbang yaitu sebesar 2\% dari APBD. Anggaran tersebut dialokasikan untuk pelaksanaan Program Prioritas Daerah yaitu : Penguatan sistem inovasi daerah,Pengembangan klaster industri unggulan daerah, Pengembangan jaringan inovasi, Pengembangan teknoprener, danPengembangan pilar-pilar tematik. Kerangka Kebijakan Inovasi yang dilakukan adalah mengembangkan iklim yang kondusif bagi inovasi dan bisnis; memperkuat kelembagaan dan daya 
dukung IPTEKIN dan mengembangkan kemampuan absorpsi oleh industri, khususnya UKM; menumbuhkembangkan kolaborasi bagi inovasi dan meningkatkan difusi inovasi, serta meningkatkan pelayanan berbasis teknologi; mendorong budaya inovasi; menumbuhkembangkan dan memperkuat keterpaduan pemajuan sistem inovasi; serta penyelarasan dengan perkembangan global.

Untuk masa ke depan, dengan tanggung jawab yang dimiliki Balitbangda saat ini pasca lahirnya PP No.38 Tahun 2017, maka kelembagaan balitbangda harus mendapatkan tambahan alokasi anggaran yang representatif untuk menunjang pelaksanaan fungsi - fungsi koordinasi inovasinya, termasuk untuk pelaksanaan kegiatan penyusunan Sistem Inovasi Daerah (SIDa) dimana Badan Penelitian dan Pengembangan berperan sebagai koordinator dalam penguatan SIDa sebagaimana tersebut di dalam Pasal 16 Peraturan Bersama Menteri Negara Riset Dan Teknologi Republik Indonesia dan Menteri Dalam Negeri Republik Indonesia No. 03 Tahun 2012 dan No. 36 Tahun 2012. Kebutuhan atas penambahan anggaran tersebut juga implikasi dari adanya peran Balitbangda dalam upaya peningkatan kapasitas dan peran ilmu pengetahuan dan teknologi. Dengan demikian, Badan Penelitian dan Pengembangan harus mampu melakukan perkiraan perhitungan terhadap semua kebutuhan anggaran secara akurat berkaitan dengan kegiatan koordinasi dan penunjang koordinasi sebagaimana tersebut di dalam PP No. 38 Tahun 2017 dan Sistem Inovasi Daerah (SiDa).

SiDa sebagai sebuah kewajiban, harus mampu diwujudkan oleh Balitbangda Kota Samarinda sebagaimana yang telah dilakukan oleh daerah lainnya di Indonesia, seperti Kota Solo. Dalam penelitian yang berjudul Studi Formulasi Kebijakan Penguatan Sistem Inovasi Daerah (SIDa) Kota Surakarta,Syarif (2017) mendeskripsikan dan menganalisis proses formulasi kebijakan penguatan SIDa di Kota Surakarta yang dilakukan oleh Badan Perencanaan Penelitian dan Pengembangan Daerah Kota Surakarta, hambatan yang muncul dari proses formulasi kebijakan penguatan SIDa, serta strategi untuk mengatasi hambatan tersebut. Metode penelitian yang digunakan adalah studi kasus dengan pendekatan kualitatif. Hasil penelitian ini menjelaskan bahwa perumusan formulasi kebijakan penguatan SIDa di Kota Surakarta sudah sesuai dasar normatif atau belum

Sementara, untuk wilayah Kalimantan, penerapan dan penguatan SIDa telah dilakukan olehKabupaten Banjar. Kabupaten Banjar telah memiliki konsep penguatan SIDa yang mana strategi dan arah kebijakan yang diambil dapat memastikan usaha-usaha yang ditempuh berjalan dengan efisien dan efektif. Strategi penguatan SIDa Kabupaten Banjar terdiri dari : 1) Penguatan Sistem Inovasi daerah berbasis agroindustri (memperkuat kelembagaan dan daya dukung ilmu pengetahuan dan teknologi atau penelitian dan pengembangan kemampuan absorsi industri, khususnya usaha mikro, kecil dan menengah, menumbuhkan kolaborasi bagi inovasi dan meningkatkan difusi inovasi, praktik baik/terbaik dan/atau hasil penelitian pengembanga, serta menumbuh kembangkan dan memperkuat keterpaduan pemajuan sistem inovasi dan klaster industri daerah). 2) Pengembangan klaster industri berbasis pertanian (agroindustri). 3) Mengembangkan jaringan inovasi agroindustri berbasis komuditas karet dan kelapa sawit dan 4) Pengembangan teknoprener (Bappelitbang Kab. Banjar, 2017).

\section{Kesiapan Balitbangda Kota Samarinda dalam Rencana Program dan Kegiatan}

Berkaitan dengan Program dan Kegiatan, Renstra Balitbangda telah mengakomodasi Program dan Kegiatan berkaitan dengan Sistem Inovasi Daerah diantara program lainnya yang akan dilaksanakan oleh Badan Penelitian dan Pengembangan dari tahun 2016 hingga tahun 2021 seperti: Program Pelayanan Adminitrasi Perkantoran, Program Peningkatan Sarana dan Prasarana Aparatur, Program Peningkatan Disiplin aparatur, Program Peningkatan Pengembangan Sistem Pelaporan Capaian Kinerja dan Keuangan, Program Peningkatan Kapasitas Sumber Daya Aparatur, Program 
Litbang Bidang SDA, Program Litbang Bidang Ekonomi dan Pembangunan, Program Litbang Bidang Pemerintahan dan Aparatur. Hal ini telah sejalan dengan yang diamanatkan oleh Peraturan Bersama Menteri Negara Riset Dan Teknologi Republik Indonesia Dan Menteri Dalam Negeri Republik Indonesia Nomor: 03 Tahun 2012 Nomor: 36 Tahun 2012 Tentang Penguatan Sistem Inovasi Daerahterutama pada Pasal 16 Ayat (1) yang menyebutkan bahwa dalam hal Penataan institusi pemerintahdilakukan dengan cara mensinergikan program dan kegiatankementerian dan lembaga dalam penguatan SIDa.Khusus SIDa, tahapan kegiatan yang telah ditetapkan antara lain :

a) Penyusunan Road Map Sistem Inovasi Daerah (SIDa) Kota Samarinda

b) Pemetaan potensi wilayah dan pengembangan produk unggulan sebagai upaya peningkatan ekonomi masyarakat

c) Penguatan sistem inovasi daerah (SIDa)

d) Pengembangan Potensi Inovasi Unggulan Daerah (SIDa) Kota Samarinda

e) Penerbitan hasil-hasil penelitian pada jurnal ilmiah yang ISSN

Di samping tantangan yang harus dijawab, renstra Balitbangda juga memuat peluang yang dapat dimanfaatkan oleh BalitbangdaKota Samarinda dalam rangka mendorong peningkatan pembangunan Kota, peluang tersebut antara lain:

1. Tenaga Aparatur Administrasi yang berkualifikasi

2. Sarana dan Prasarana sesuai dengan kebutuhan kantor

3. Terbukanya kesempatan mengikuti Bimbingan Teknis

4. Peraturan yang mengatur tentang keijakan teknis yang harus diambil melalui kajian

5. Banyak Isu aktual yang ada di masyarakat dan SKPD yang melakukan kegiatan secara mendalam sehingga terbukannya peluang bagi Badan Penelitian dan PengembanganKota Samarinda Untuk melakukan Penelitian dan Kajian.

Dari peluang di atas,peluang nomor 3 dan 5 bisa menjadi modal utama Balitbangdauntuk dapat beradaptasi berdasarkan kondisi kebaruan lembaga tersebutdalam menjalankan tugas pokok dan fungsinya dengan penjelasan sebagai berikut:

- Terbukanya kesempatan mengikuti Bimbingan Teknis

Terbukanya kesempatan bagi para pegawai Balitbangdauntuk mengikuti Bimtek (khususnya pegawai yang berada di Bidang Inovasi), akan membantu para SDM tersebut untuk mengupgrade pengetahuan sesuai dengan kebutuhan perkembangan organisasi (lembaga). Guna lebih memaksimalkannya, maka, bimtek yang akan diikuti harus yang sesuai dengan kebutuhan organisasi agar bisa aplikatif di tempat kerja, seperti bimtek mengenai IT (sistem) yang banyak dibutuhkan untuk menghasilkan inovasi daerah.

- Banyak Isu aktual yang ada di masyarakat dan SKPD yang melakukan kegiatan secara mendalam sehingga terbukannya peluang bagi Badan Penelitian Kota Samarinda Untuk melakukan Penelitian dan Kajian. Semakin banyak isu aktual yang diketahui oleh Balitbangda, akan memperkaya perspektif analisis dan evaluasi atas upaya-upaya penetapan inovasi daerah.

\section{Strategi Balitbangda Kota Samarinda dalam Penerapan PPNo. 38 Tahun 2017}

Balitbangda Kota Samarinda perlu menyusun strategi untuk mengakselerasi penerapan PP No. 38 Tahun 2017 agar dapat bersaing dengan daerah lain dalam hal inovasi daerah. Mengadopsi pemikiran dari Taufik (2013) mengenai Strategi Multidimensi Penguatan Sistem Inovasi, yang dapat dilakukan oleh Balitbangda Kota Samarinda berdasarkan strategi multidimensi tersebut adalah : 
1. Lokalitas Teritorial : keragaman daerah, kewilayahan, keruangan, geografis, sosio kultural, sistem pemerintahan ekosistem daerah bagi perkembangan kreativitas-keinovasian di daerah.

Berdasarkan Surat Edaran Kemendagri No. 060/2700/LITBANG tahun 2016 tentang Pedoman Arah Penataan Kelembagaan Litbang di lingkungan Pemda sesuai PP No. 18 Tahun 2016 tentang Perangkat Daerah, untuk meningkatkan kinerja penyelenggaraan pemerintahan daerah harus dilakukan penguatan kelembagaan penelitian dan pengembangan yang menjadi kewenangan pemerintah daerah. Harapannya para Gubernur, Bupati/Walikota memperhatikan beberapa hal diantaranya : mengarahkan penguatan kebijakan inovasi daerah; dan meningkatkan kapasitas Badan Penelitian dan Pengembangan diantaranya penataan kelembagaan, peningkatan kualitas tenaga fungsional peneliti dan perekayasa, penyusunan sistem dan prosedur yang berstandar, dan pengembangan sarana dan prasarana yang memadai dan membangun jejaring yang relevan.

2. Industrial : keragaman dan karakteristik industri daya saing industrial dan industri berpotensi unggul. Berkaitan dengan keindustrian yang merupakan simbol dari kegiatan perekonomian, berbagai inovasi yang akan dilakukan/dihasilkan di lingkungan Pemkot Samarinda ke depan (sebagaimana yang akan dirancang dalam dokumen Sistem inovasi daerah (SIDa) harus mampu melakukanmapping secara sistematis dan mendalam guna menggali berbagai potensi ekonomi di Pemkot Samrinda. Dengan industri-industri yang terpetakan dengan baik, diharapkan akan dapat membantu Pemerintah Kota Samarinda dalam mengembangkan kekuatan perekomiannya sebagai modal daya saingnya.

3. Pengetahuan : jaringan inovasi (hubungan, kemitraan, dinamika interaksi) dinamika perkembangan, aliran dan pemanfaatan pengetahuan. Kegiatan inovasi bukanlah kegiatan yang eksklusif (hanya birokrat saja yang terlibat di dalamnya), untuk mewujudkannya harus melibatkan berbagai stakeholders (lembaga pendidikan, lembaga penunjang inovasi, dunia usaha, dan masyarakat di daerah) guna dapat memberikan konstribusinya berdasarkan keahlian dan kemampuannya masing-masing. Dengan semua stakeholders terlibat di dalamnya, maka akan dapat lebih diketahui apa yang harus menjadikebutuhan inovasi di daerah. Aspek pengetahuan sangat relevan dengan apa yang tersebut di dalam peraturan bersama antara Menristek dan Mendagri No. 3 Tahun 2012 dan No. 36 tahun 2012 tentang penguatan sistem inovasi daerah, dimana di dalamnya tersebut bahwa Inovasi adalah kegiatan penelitian, pengembangan, penerapan, pengkajian, perekayasaan, dan pengoperasian yang bertujuan mengembangkan penerapan praktis nilai dan konteks ilmu pengetahuan yang baru atau cara baru untuk menerapkan ilmu pengetahuan dan teknologi yang telah ada ke dalam produk atau proses produksi.

4. Aktor Inovasi : teknoprener penguatan bisnis inovatif dan modernisasi/revitalisasi.

Salah satu tantangan inovator adalah inovasi yang dihasilkan mampu menciptakan bisnis proses yang ekonomis. Bukan rahasia lagi jika berbagai upaya perubahan selalu berbiaya mahal. Inovator yang hebat bisa menekan segala perubahan yang akan dilakukan dengan perhitungan yang smart dan ekonomis. Pertimbangan-pertimbangan ekonomis, pertumbuhan dan hambatanhambatan. Tidak diragukan lagi, berbagai perubahan organisasi bertujuan untuk menyempurnakan efektivitasnya. Pekerjaan-pekerjaan yang bersifat ganda, pegawai-pegawai yang tidak memiliki pengalaman dan tidak terlatih khusus serta pemborosan biaya, merupakan beberapa diantara sekian banyak sebab yang merubah suatu organisasi (Terry, 2016: 121). 


\section{E. PENUTUP}

\section{Kesimpulan}

Dari berbagai analisis terhadap kondisi Balitbangda saat ini terhadap peraturan dan teori inovasi, dapat disimpulkan beberapa upaya yang dapat dilakukan untuk penguatan Balitbangda Kota samarinda sebagai berikut :

1. Badan Penelitian dan Pengembangan harus mempunyai pemahaman yang baik mengenai kriteria inovasi daerah sebagai dasar bahan evaluasi sesuai dengan tugasnya. Kriteria dasar yang harus dimengerti antara lain : kualifikasi pembaharuan, kemanfaatan bagi daerah dan masyarakat serta pemahaman akan replikasi (mampu melakukan perhitungan-perhitungan kegiatan replikasi).

2. Badan Penelitian dan Pengembangan harus memiliki kemampuan koordinatif serta memiliki daya komunikasi yang baik.

3. SDM Balitbangda Kota Samarinda harus memiliki kapasitas yang cukup, baik secara kualitas maupun kuantitas.

4. Badan Penelitian dan Pengembangan mempunyai fungsi koordinatif yang sangat luas ruang lingkupnya di lingkup Pemkot Samarinda. Point koordinatif tersebut harus dapat tersebutjelas dalam Visi. Dengan penyebutan secara jelas ke dalam Visi, maka akan menjadi patokan dalam merumuskan tugas dan fungsi bidang dan subbidang yang ada di lingkungan Balitbangda.

5. Dari ketiga misi Badan Penelitian dan Pengembangan Kota Samarinda, juga belum terlihat adanya misi berkaitan dengan inovasi. Kondisi tersebut dapat menghambat proses pencapaian visi dan perencanaan. Bagaimanapun juga keberadaan misi akan sangat membantu untuk menjadi kaitan dalam membuat dan menentukan rancangan pelaksanaan program dan kegiatan.

6. Pagu anggaran Balitbangda untuk melakukan tugas barunya berdasarkan PP No. 38 Tahun 2017 belum representatif. Sebagai gambaran, dengan sifat kerja yang sama untuk melakukan koordinatif, pagu anggaran Balitbangda tersebut kalah jauh jumlahnya dengan besaran anggaran Bappeda.

\section{Rekomendasi}

1. Sudah saatnya Pemerintah Kota Samarinda memberikan porsi anggaran lebih besar kepada Balitbangda guna melakukan fungsi - fungsi koordinatif inovasinya, termasuk untuk pelaksanaan kegiatan penyusunan Sistem Inovasi Daerah (SIDa) dimana Badan Penelitian dan Pengembangan berperan sebagai koordinator dalam penguatan SIDa.

2. Perlu dilakukan review terhadap renstraBadan Penelitian dan Pengembangan agar dapat lebih teraplikasiberbagai pelaksanaan tugas dan fungsi Balitbangda yang baru berdasar PP No. 38 Tahun 2017. Review renstra juga akan membantu Badan Penelitian dan Pengembangan dalam memandu target kinerjanya sebagai leading inovasi di daerah.

3. Peningkatan kapasitas pegawai secara memadai, baik dari segi kuantitas dan kualitas dapat dilakukan dengan membuat telaah staff yang dapat menggambarkan secara konkrit peta kompetensi pegawai yang dibutuhkan, termasuk kebutuhan akan adanya fungsional peneliti di dalamnya.

4. Perlu dilakukan restrukturisasi budaya kerja di Badan Penelitian dan Pengembangan Kota Samarinda. Sifat kerja yang sebelumnya bersifat eksklusif berubah ke inklusif tentu menimbulkan shock culture.Karenanya perlu upaya menemu kenali kembali nilai-nilai Balitbangdaterbaru di masing-masing diri aparatur yang ada di lingkungan Balitbangda Kota samarinda. 


\section{DAFTAR PUSTAKA}

Akmal, Putri. (2017). Kemenkominfo Pilih 'Smart Kampung’ Banyuwangi jadi Smart City. https://news.detik.com/berita-jawa-timur/d-3508970/kemenkominfo-pilih-smart-kampungbanyuwangi-jadi-smart-city. Diunduh 29 Oktober 2017

Anthony, Scott D. 2013. The Litte Black Book of Innovation, Bagaimana Inovasi Bekerja : Bagaimana Kita Melakukannya. Elex Media Komputindo. Jakarta.

Bappeda Kota Samarinda. (2017). Perubahan RKPD (Rencana Kerja Pemerintah Daerah) Kota Samarinda Tahun 2017. https://bappeda.samarindakota.go.id/produk/read/rencanakerja-pembangunan-daerah-rkpd-tahun-2017. Diunduh 18 Desember 2017.

Bappelitbang Kabupaten Banjar. (2017). Laporan Akhir Roadmap Sistem Inovasi Daerah Kabupaten Banjar. Daring: http://bappelitbang.banjarkab.go.id/konten/uploads/downloads/ 2017/08/2014-Road-Map-Sistem-Inovasi-Daerah-SIDa-Kabupaten-Banjar-Protect. pdf. Diakses 13 Desember 2017.

CNN Indonesia. (2017). Naik ke Peringkat 72, Kemudahan Berbisnis RI di Bawah Vietnam. Diunduh tanggal 1 November 2017 dari Daring : https:/www.cnnindonesia.com/ekonomi/ 20171101082939-92-252614/naik-ke-peringkat-72-kemudahan-berbisnis-ri-di-bawahvietnam/. Diakses tanggal 1 November 2017.

Drucker, Peter F. 2017. Inovasi dan Kewirausahaan, Praktek dan Dasar-Dasar. Jakarta: Erlangga.

Fontana, Avanti. 2011. Innovation We Can : Manajemen Inovasi dan Penciptaan Nilai Individu, Organisasi, Masyarakat. Jakarta: Cipta Inovasi Sejahtera.

Istijanto. (2005). Riset Sumber Daya Manusia. Jakarta : PT. Gramedia Pustaka Utama.

Kast, Fremont E. dan James E. Rosenzweig. (2007). Organisasi dan Manajemen. Jakarta: PT. Bumi Aksara.

LAN, 2016. Takdir Samarinda Menjadi Kota Inovasi. Daring: http//lan.go.id/id/berita-perwakilan/ takdir-samarinda-menjadi-kota-inovasi 26 Januari 2016. Diunduh 2 Oktober 2017.

Makmur dan Rohana Thahier. (2015). Inovasi dan Kreatifitas Manusia dalam Administrasi dan Manajemen. Bandung : PT.Refika Aditama.

Sekretariat Kabinet. (2017). Presiden Teken PP Payung Hukum terhadap Inovasi Dalam penyelenggaraan Pemerintah Daerah. Daring: http://setkab.go.id/presiden-teken-pppayung-hukum-terhadap-inovasi-dalam-penyelenggaraan - pemerintah-daerah/. Diakses 10 November 2017.

Setyowati, Desy. (2017). Bappenas Lihat 3 Kunci Sukses Inovasi Pembangunan di Daerah. Daring : https://katadata.co.id/berita/2017/01/11/pemerintah-minta-kepala-daerah-kreatifjangan-andalkan-pusat. Diakses tanggal 1 November 2017.

Solehudin, imam. (2017). Sukses Bangun Sulsel, Syahrul Limpo Dianugerahi Kepala Daerah Inovatif. Daring : https://www.jawapos.com/read/2017/08/02/148242/sukses-bangun-sulsel- syahrullimpo-dianugerahi-kepala-daerah-inovatif. Diakses tanggal 1 November 2017. 
Syarif, Muhammad. (2017). Studi Formulasi Kebijakan Penguatan Sistem Inovasi Daerah (SIDa) Kota Surakarta. Working PaperJuly 2017. DOI: 10.13140/RG.2.2.22137. 36967. Daring: https://www.researchgate.net/publication/318147790. Diakses 13 November 2017. Hal.116.

Taufik, Tatang A. (2013). Contoh Implementasi Penguatan Sistem Inovasi di Beberapa Kabupaten/ Kota. Workshop DRN - DRD "Penguatan Sumberdaya, Kelembagaan, dan Jaringan Iptek Pusat dan Daerah Untuk Peningkatan Daya Saing dan Kemandirian Bangsa” Ruang Komisi Utama BPPT, Badan Pengkajian dan Penerapan Teknologi. Jakarta, 4 Desember 2013.

Terry, George R. (2016). Prinsip-Prinsip Manajemen. Jakarta: PT. Bumi Aksara.

Utomo, Tri W.W. (2017). Inovasi Harga Mati. Depok: T. RajaGrafindo Persada.

Wismono, F.H. (2016). Inovasi Sebagai Gaya Hidup Baru Kota Samarinda. Daring : https:// www.kompasiana.com/efhawe/inovasi-sebagai-gaya-hidup-baru-kotasamarinda_5864ca58f87e61d4063c560d. Diakses tanggal 31 Oktober 2017.

\section{Peraturan Perundangan}

Undang-Undang No. 23 Tahun 2014 tentang Pemerintah Daerah

Peraturan Pemerintah No. 18 tahun 2016 tentang Perangkat Daerah

Peraturan Pemerintah No. 38 Tahun 2017 tentang Inovasi Daerah

Peraturan Bersama Menteri Negara Riset Dan Teknologi Republik Indonesia Dan Menteri Dalam Negeri Republik Indonesia No. 03 Tahun 2012 No. 36 Tahun 2012 
